\title{
COMPARATIVE EFFICIENCY OF BIOFLOC AND FEED BASED CULTURE OF COMMON CARP (CYPRINUS CARPIO L.)
}

\author{
M. SARKER, S. K. DAS ${ }^{* 1}$ AND B. MONDAL ${ }^{1}$ \\ Fishery Extension Officer \\ Ramnagar-1 Block, Purba Medinipur \\ Pin- 721 448, West Bengal, India
}

\begin{abstract}
Biofloc technology is an environmentally sound aquaculture production system in which nutrients are continuously recycled and reused. In biofloc based production systems, integration of heterotrophic bacteria and algae is grown simultaneously forming flocs under controlled conditions in situ. The carbon sources of the culture system are proved to be limiting in biofloc formation, composition and its nutritive values. With the above background, the present study on comparative efficiency of biofloc and feed based culture of common carp (Cyprinus carpio L.) has been envisaged. The findings of the study indicated that biofloc alone was not sufficient enough for the comparable growth of the test fish under supplementary feeding regime. Biofloc alone resulted only in 2.79 times absolute weight gain against 9.27 times with only feed @ $6 \%$ body weight per day, however, mortality rate of the test fish was highest $(33.33 \%)$ in biofloc treatment alone. It was clear that biofloc improved the performance of the supplementary feed both in terms FCR and FCE. Presence of biofloc improved the FCR from 1.75-2.09 to 2.31 in control. In spite of less absolute weight gain with feeding @ 3\% body weight per day because of the most favourable FCR and less nutrient loading, the system was proved to be economically and ecologically more sustainable in presence of biofloc.
\end{abstract}

Key words: Biofloc, Cyprinus carpio L., FCE, FCR

Global aquaculture production continued to increase parallel with declining capture fishery production in recent times. Contribution of aquaculture increased from $13.4 \%$ to $42.2 \%$ during 1990 to 2012 (FAO, 2014) and the role of aquaculture in supplying animal protein to the global population is well documented (Tidwell and Allan, 2001; Sugiyama et al., 2004). Animal husbandry and fisheries are the two sources of animal protein for the world population while fish and allied aquaculture products are considered to be the safest among the proteins from animal sources (MPEDA, 1992) containing all essential amino acids, and are excellent source of unsaturated fatty acids (de Deckere et al., 1998; Horrocks and Yeo, 1999; Connor, 2000; Ruxton et al., 2005).

Aquaculture production depends largely upon the ambient nutrients as proper nutrient balance is important in maintaining growth and fish health towards higher production. The costs of the ingredients used in fish feed escalated between $20 \%$ and $92 \%$ during 2007 - 2008 (FAO, 2010). Aquafeed, being considered the most vital input cost, occupies almost 50-70\%

*Corresponding Author

${ }^{1}$ Department of Aquaculture, F/o Fishery Sciences, WBUAFS, Chakgaria, Kolkata 700 094, W.B., India 
of the budget allocation for production (Anon, 1983; Veerina et al., 1993). Moreover, with the increasing demand of seafood for human consumption, the demand for such used by the industrial sector for processing of fishmeal and fish oil products also increased (Péron et al., 2010). About 5-6 million tonne of low-value trash fish are used as feed in aquaculture (FAO, 2010) and an estimated $1.9 \mathrm{~kg}$ of wild fish is required for production of one kilogram of fish (Naylor et al., 2000). Therefore, studies on the development of feed substitution strategies with a minimal input of fishmeal and fish oil has been emphasized where fish products are being replaced by alternative, cheaper plant protein sources. Such studies on alternative protein inputs have resulted in considerable reduction in production costs (Albuquerque et al., 2014) and contributed higher economic viability in animal production including aquaculture (Santos et al., 2013).

The biofloc technology involves an unconventional way of thinking which deviates from the common mind-set that clear water is best for aquaculture (Avnimelech, 2012; Hargreaves, 2013). It is basically the recycling of waste to protein enriched biofloc as a natural live food within the culture system. Biofloc technology encourages suspended growth of flocs consisting of phytoplankton, microbes, and aggregates of living and dead particulate organic matter and grazers of bacteria (Hargreaves, 2006) with a view to recycle feed residues and to increase feed efficiencies. It enhances the use of a microbial community to produce a supplementary microbial food source, high protein bioflocs, which can be utilized by species capable of filter-feeding (Avnimelech, 2012). By adding cheap carbohydrate sources, heterotrophic bacterial growth within the pond is stimulated and microbial mobilization of nitrogen through the production of microbial proteins are encouraged (Avnimelech, 1999). Sufficient aeration and mixing is required to keep the floc in suspension in the water, which allows the water quality to be controlled (Hargreaves, 2013).The microbial community, predominantly heterotrophic bacteria, within the water acts as a biofilter, resulting in nitrogen uptake and reducing ammonia $\left(\mathrm{NH}_{4}\right)$ levels faster and more efficiently than the nitrification process (Avnimelech, 1999; Crab et al., 2012). Ammonium immobilization by heterotrophic bacteria takes place rapidly because the growth rate and microbial biomass yield per unit substrate of heterotrophs are higher by an order of magnitude compared to that of nitrifying bacteria (Hargreaves, 2006). Biofloc has been focused internally as an alternative protein for fish meal, mainly produced as microbial meal (Kuhn et al., 2009). They are irregular in shape, having variably distributed particle size, fine, easily compressible and highly porous ( $>99 \%$ porosity) and are highly permeable (Chu and Lee, 2004). These systems have very low water exchange, and thus have a significantly lower impact on the surrounding environment through lower water requirements and minimal to no effluent water discharge (Avnimelech, 2007; Avnimelech, 2012; Hargreaves, 2013). Degradation of the environment is further reduced by the lower amount of pelleted feed needed and the efficiency in recycling nutrients from the fish waste and uneaten feed (Hargreaves, 2013). The success of this technology primarily depends upon the species of culture as the cultured species should have the ability to graze the bacterial flocculates efficiently and should have the ability to digest and incorporate the microbial protein (Tacon et al., 2002; Burford et al., 2004). 
With this background the present research was conducted to evaluate the potential of biofloc in supporting the growth of benthivorous common carp (Cyprinus carpio L.) in experimental culture units.

\section{MATERIALS AND METHODS}

The present study was conducted in the Department of Aquaculture, Faculty of Fishery Sciences, West Bengal University of Animal and Fishery Sciences, Chakgaria, Panchasayar, Kolkata-94 ( $22^{\circ} 28^{\prime} 46 " \mathrm{~N} 88^{\circ} 24^{\prime} 4 " \mathrm{E}$ ). The duration of the study lasted for a period of about three months from April-June, 2015.

Experimental set up: Fifteen ( 180 L) outdoor experimental cylindrical cement tanks (diameter: $\sim 48 \mathrm{~cm}$, length: $100 \mathrm{~cm}$ ) were selected for the present investigation. After thorough washing and sun drying the tanks were provided with agriculture soil base of 15 $\mathrm{cm}$ and then filled with ground water $(\mathrm{pH}-7.5$, alkalinity- $124 \mathrm{mg} \mathrm{L}^{-1}$, hardness- $631 \mathrm{mg} \mathrm{L}^{-1}$ ). All the tanks were manured with cow dung @ $10,000 \mathrm{~kg} \mathrm{Ha}^{-1}$ as practiced in traditional pond preparation for fish farming. The estimated amount of cow dung was mixed with water in a bucket and dispensed as slurry into the tanks. All the tanks were treated with lime @ $200 \mathrm{~kg} \mathrm{Ha}^{-1}$ following one week of manure application and kept undisturbed for another one week. Then they were divided into five batches $\left(\mathrm{T}_{1}, \mathrm{~T}_{2}, \mathrm{~T}_{3}, \mathrm{C}_{1}, \mathrm{C}_{2}\right)$ in triplicate by complete randomized design and when the water colour turned to bluish green, 18 nos. of healthy fry of common carp (Cyprinus carpio L.) average wt. $0.841 \mathrm{~g}(0.845 \pm 0.855 \mathrm{~g})$ and average length $4.8 \mathrm{~cm}(4.5 \pm 5.1 \mathrm{~cm})$ collected from faculty pond were stocked in $\mathrm{T}_{1}, \mathrm{~T}_{2}, \mathrm{~T}_{3}$ and $\mathrm{C}_{1}$ batches of the tanks.

Preparation of biofloc: $150 \mathrm{~L}$ of boiled rice water was mixed with $3 \mathrm{~kg}$ molasses in a tub.
After that, yeast powder $(250 \mathrm{~g})$ and filtered fresh water $(50 \mathrm{~L})$ were added to the mixture and vigorously mixed together to make a solution and also kept for 72 hours in open air for aerobic fermentation. When the colour of solution turned into deep yellow the solution was transferred to another tub. Finally the solution was ready to use as a medium of biofloc growth enhancer.

Feeding: Fish in first $\left(T_{1}\right)$ and second $\left(T_{2}\right)$ batches of treatment tanks were fed with crumble feed (crude protein: $35 \%$ ) once daily between 9.00 a.m. to 10 a.m. @ 6\% and 3\% of body weight respectively along with biofloc medium @ 15 mL/tank. Fish in the third batch of tanks $\left(\mathrm{T}_{3}\right)$ were applied only with biofloc medium @ $15 \mathrm{~mL} /$ tank daily without the above supplementary feed. Fish in the fourth batch of tanks $\left(C_{1}\right)$ were supplied only with the above diet @ 6\% of body weight but were not applied with biofloc medium and the last batch of treatment tanks without fish was applied only with biofloc medium @ $15 \mathrm{~mL} / \mathrm{tank}$ daily acted as second control $\left(\mathrm{C}_{2}\right)$. The required amount of feed was broadcasted over the water surface in respective treatments $\left(T_{1}, T_{2}\right.$ and $\left.C_{1}\right)$. The biofloc medium was also broadcasted by using a measuring cylinder over the water surface of respective treatments $\left(\mathrm{T}_{1}, \mathrm{~T}_{2}, \mathrm{~T}_{3}\right.$ and $\left.\mathrm{C}_{2}\right)$. The biofloc medium was applied to the treatments once daily at early morning between 5.30 a.m. to 6 a.m. or late afternoon between 5 p.m. to 5.30 p.m. up to 45 days of the investigation period. All the tanks were aerated by two electromagnetic air pump (35 Watt and 220 Volt each), attached with two pumice stones in each tank which were placed $40 \mathrm{~cm}$ above the bottom surface and was continued for 12-14 hours per day depending upon the daily weather condition as during cloudy days duration of aeration was more. 
Collection of samples: Water samples were collected at weekly intervals from each of the tanks at 9.00 a.m. from $15 \mathrm{~cm}$ depth for physico-chemical analyses. Collection of water samples were done carefully so as to prevent air bubbling. Soil samples were collected from each of the cisterns at fortnightly intervals. The soil samples were air dried, pulverized, sieved $(150 \mu \mathrm{m}$ mesh) and stored in labelled polythene packets for analyses.

\section{Analysis of sample \\ Physico-chemical parameters of water and sediment: Selective water quality parameters like temperature, $\mathrm{pH}$, total alkalinity, hardness, dissolved oxygen and $\mathrm{BOD}_{1}$ were measured following the methods of APHA (1995). Surface water temperature was measured using a centigrade thermometer (Hanna HI98127) and $\mathrm{pH}$ of water samples was measured using a digital $\mathrm{pH}$ meter (Systronics VI). Nutrient parameters like ammonia-nitrogen $\left(\mathrm{NH}_{3} \mathrm{~N}\right)$, nitrate-nitrogen $\left(\mathrm{NO}_{3} \mathrm{~N}\right)$ (EPA, 2009) and ortho phosphate (APHA, 1995) were also measured using spectro photometric method through a double beam UV-Vis spectrophotometer (CECIL CE 4002).}

Sediment physico-chemical parameters were measured following the procedures of Walkley and Black (1934) for organic carbon and available phosphorus by Jackson (1967) respectively and $\mathrm{pH}$ was measured using digital pH meter (Systronics VI) (APHA, 1995).

Fish growth: Fish growth was recorded at 15 days intervals from each cistern. Half of the stocked fish were caught randomly with a hand net and their weight $(\mathrm{g})$ increments were recorded for estimation of average weight gain, specific growth rate (SGR), feed conversion ratio (FCR) and protein efficiency ratio (PER).
They were then released again as quickly as possible for further growth. The following estimates were done as:

Net B. Wt. gain $=($ Final - Initial $)$ B. Wt

Body wet weight gain $(\%)=($ Final - Initial $)$ B. Wt. x 100 Initial B. Wt.

Feed conversion ratio $(\mathrm{FCR})=$ Total dry feed fed (De silva and Anderson, 1995) Wet weight gain Specific growth rate $(\%)=\ln ($ Final B . WT. $)-\ln ($ Initial B. Wt. $) \times 100$ Number of days

Feed conversion efficiency $(\mathrm{FCE})=\underline{\text { Weight gain } \mathrm{x} 100}$ (Goddard, 1996) Food consumed

Mortality rate $(\%)=($ Initial - Final $)$ no. of fish $\times 100$ Initial no. of fish

Statistical analyses: All the results were subjected to statistical analysis. One way analysis of variance (ANOVA) was applied to test the significance of difference among the treatments. Correlation coefficient (r) test was applied to establish relationship between selective parameters using appropriate software.

\section{RESULTS}

Biofloc characteristics: Qualitative examination of biofloc indicated that the flocs were principally composed of heterotrophic bacteria, phytoplankton, zooplankton and protozoa. The crude protein, crude lipid and ash content of the floc did not differ significantly and ranged from $18.5-19.22 \%, 0.55-0.62 \%$ and $49.56-51.45 \%$ respectively.

Growth of fish: Mortality of common carp fry was highest $(33 \%)$ in only biofloc system without any supplements feeding. Weight of fish continued to increase over time in any case and the overall mean value was highest (4.65 $\mathrm{g}$ ) in $T_{1}$ and lowest in $T_{3}$. Temporal trend of 
weight gain (\%) declined sharply as the period of rearing progressed (Fig. 1). The average value was maximal in $\mathrm{T}_{1}(54.47 \%)$ followed by $\mathrm{C}_{1}(50.15 \%), \mathrm{T} 2(43.88 \%)$ and lowest in $\mathrm{T}_{3}$ (27.73\%) (Fig. 2). Temporal trend in SGR (specific growth rate) of fish among the treatments was distinctly different from one treatment to another (Fig. 3). The overall mean was highest in $\mathrm{T}_{1}(9.27 \%)$ and lowest in $\mathrm{T}_{3}$ (2.59\%). Absolute growth of fish in $\mathrm{T}_{1}$ and $\mathrm{C}_{1}$ was distinctly higher by $62.41 \%$ and $29.97 \%$ compared to $\mathrm{T}_{2}$ and $\mathrm{T}_{3}$ respectively (Fig. 4).

Water and soil quality: Surface water temperature did not differ among the treatments and ranged from $31-36^{\circ} \mathrm{C}$. Water $\mathrm{pH}$ remained alkaline $(7.1-8.2)$ in all the treatments with strong significant difference $\left(\mathrm{F}_{4,13}=11.57\right.$, $\mathrm{P} \leq 0.01$ ) among them (Table 1). Total alkalinity remained congenial and the highest mean value was encountered in $\mathrm{T}_{3}\left(134.28 \pm 2.78 \mathrm{mg} \mathrm{L}^{-1}\right)$ and lowest in $\mathrm{T}_{2}$ with marginal significant difference among the treatments $\left(\mathrm{F}_{4,13}=3.186\right.$, $\mathrm{P} \leq 0.05$ ). However, highest mean value of water hardness was encountered in $T_{1}$ and lowest in $\mathrm{T}_{3}$ (Table. 1) where treatment difference was significant $\left(\mathrm{F}_{4,13}=7.85, \mathrm{P}<0.01\right)$. Dissolved oxygen of water ranged from $6.2-9.3 \mathrm{mg} \mathrm{L}^{-1}$ in the treatments during the study period with insignificant treatment difference $(\mathrm{P} \leq 0.05)$ (Table1). However, strong significant difference $\left(\mathrm{F}_{4,13}=15.4, \mathrm{P}<0.001\right)$ of $\mathrm{BOD}_{1}$ was observed among the treatments with highest mean value $\left(3.54 \pm 0.22 \mathrm{mg} \mathrm{L}^{-1}\right)$ in $\mathrm{T}_{1}$ and lowest $\left(2.36 \pm 0.126 \mathrm{mg} \mathrm{L}^{-1}\right)$ in $\mathrm{C}_{2}$. The highest mean values of ammonia- $\mathrm{N}$ and nitrate- $\mathrm{N}$ was observed in $\mathrm{C}_{1}$ and $\mathrm{T}_{1}$ respectively (Table 1 ) and in both the cases treatment differences were significant $\left(\mathrm{F}_{4,13}=17.6, \mathrm{P}<0.05\right.$ and $\mathrm{F}_{4,13}=$
$16.64, \mathrm{P}<0.001)$. Nitrate- $\mathrm{N}$ was conspicuous by it's absence during most part of the investigation period in all the treatments. Ortho phosphate concentration was highest in $\mathrm{T}_{1}$ and lowest in $\mathrm{C}_{2}$ with significant difference $\left(\mathrm{F}_{4,13}=\right.$ $33.18, \mathrm{P}<0.001)$ among the treatments (Table 1).

Physicochemical parameters of sediment indicated alkaline condition in all the treatments (Table 1). Organic carbon content of sediment $\left(\mathrm{F}_{4,13}=27.63, \mathrm{P}<0.001\right)$, available-P content of sediment differed significantly $\left(\mathrm{F}_{4,13}=41.6\right.$, $\mathrm{P}<0.001$ ) (Table 1).

\section{DISCUSSION}

Absolute weight gain of the test fish (Cyprinus carpio $\mathrm{L}$.) decreased polynomially $\left(\mathrm{y}=-0.562 \mathrm{x}^{2}\right.$ $\left.+0.745 x+8.255 ; R^{2}=0.991\right)\left(\right.$ Fig. 5 ) from $T_{1}$ to $\mathrm{T}_{3}$ either with decreasing ration size from $6 \%$ to $3 \%$ or with and without biofloc supplementation. Therefore, it was established that both the rate of supplementary feed application and nutritionally rich biofloc exerted a definite role in growth of the test fish. Moreover, such intensity of impact upon growth of the fish was extremely discernible among the treatments where in presence of biofloc, feed application @ 6\% body weight $\left(\mathrm{T}_{1}\right)$ resulted in absolute weight gain $(\%)$ by an order of magnitude (Fig. 6) against $6.07 \%$ in $\mathrm{T}_{2}$ (@3\% feed). However, comparing an iso-nutrient regime in $\mathrm{T}_{1}$ and $\mathrm{C}_{1}$ effect of biofloc in increasing the absolute weight gain was only $6.42 \%$ in $\mathrm{T}_{1}$. Again, biofloc in $\mathrm{T}_{3}$ resulted only in 2.79 times absolute weight gain against 9.27 times with only feed @ 6\% body weight. Therefore, biofloc alone was not sufficient, for the comparable growth of the test fish under supplementary feeding regime. This was further evidenced from the mortality of the test fish 


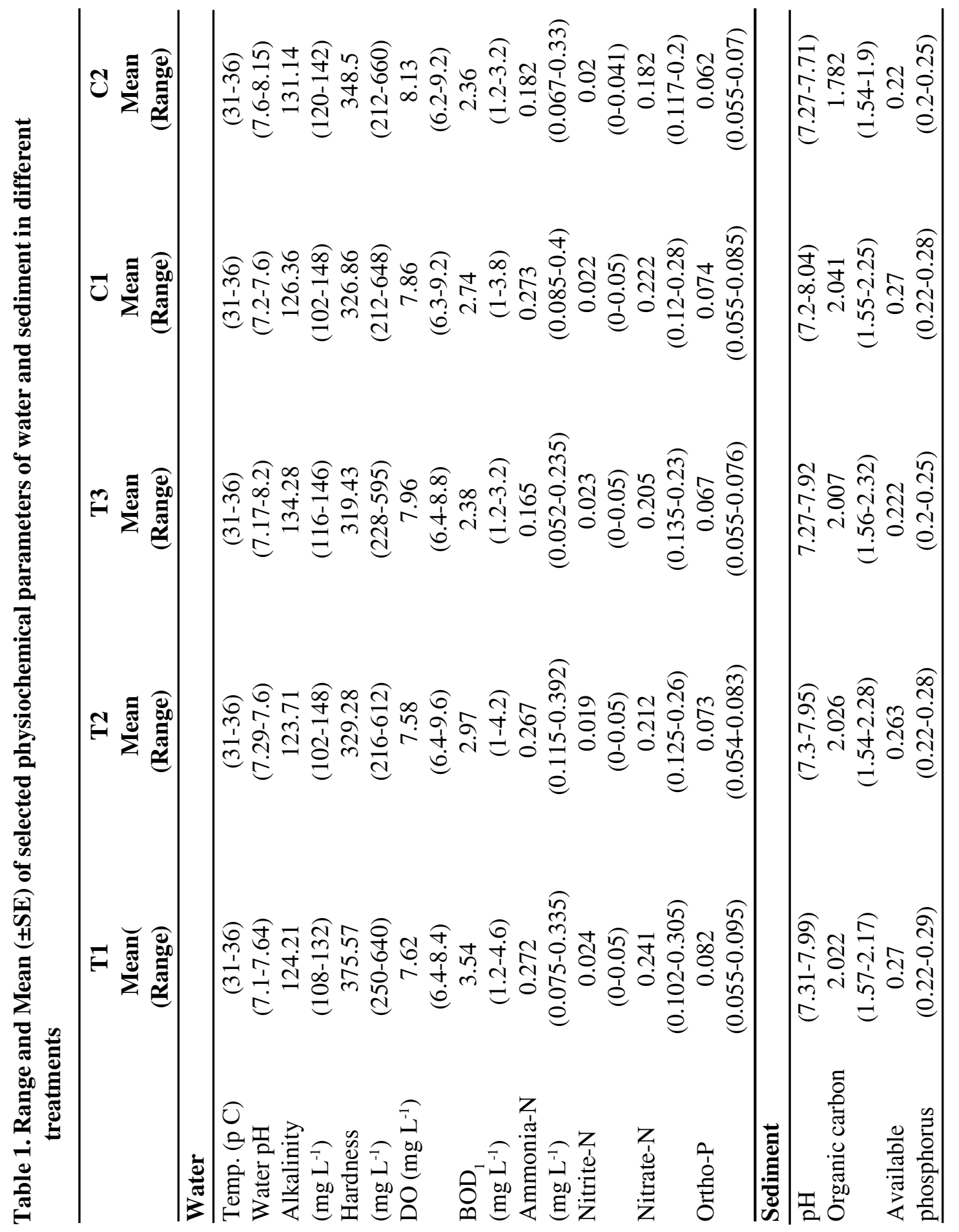




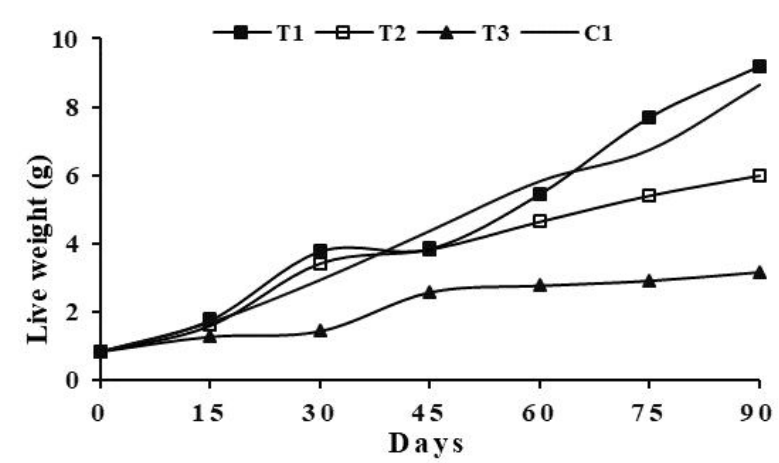

Fig. 1. Temporal trend in growth of common carp in different treatments employed

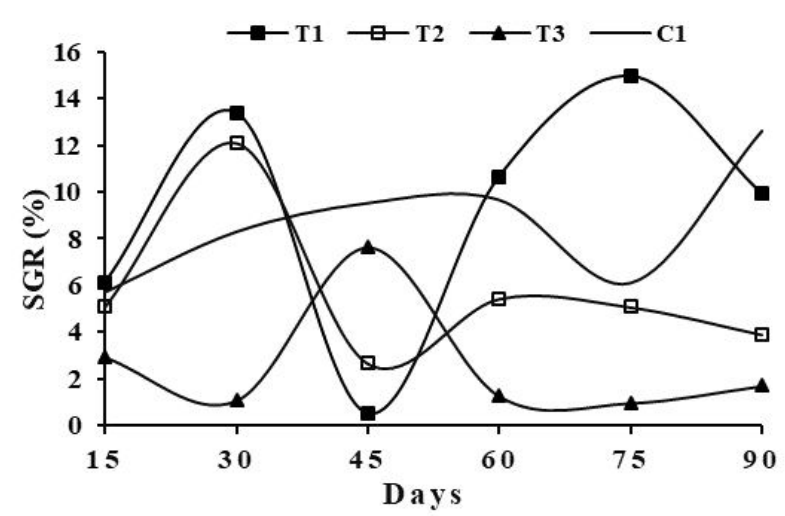

Fig. 3. Temporal trend in specific growth rate (\%) of common carp in different treatments employed

which was highest (33.33\%) in the biofloc alone treatment $\left(\mathrm{T}_{3}\right)$ and such rate declined by a modular pattern $\left(\mathrm{y}=30.68 \mathrm{x}^{-0.60} ; \mathrm{R}^{2}=0.89\right)$ either with feeding support alone or both with feeding and biofloc support (Fig. 7).

However, presence of biofloc improved the FCR both in $\mathrm{T}_{1}(2.09)$ and $\mathrm{T}_{2}(1.75)$ against $\mathrm{C}_{1}$ (2.31). Therefore, in spite of decrease in absolute weight gain in $\mathrm{T}_{2}$, because of the most favourable FCR (Fig. 8) and less nutrient loading, the system was proved to be economically and ecologically more supportive. This was further corroborated by

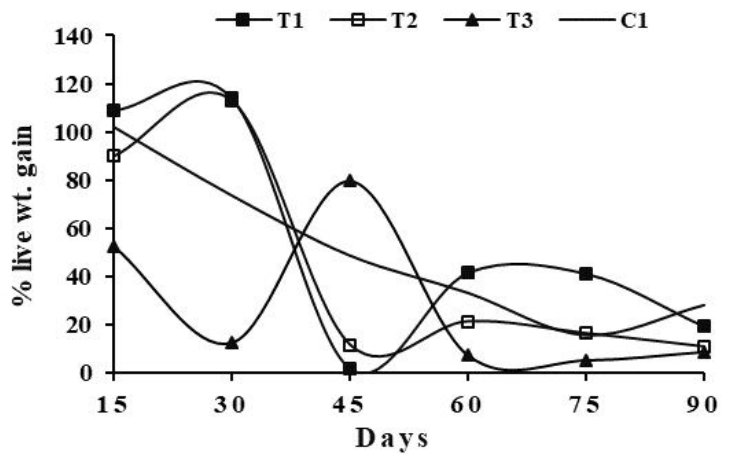

Fig. 2. Temporal trend in live weight gain (\%) of common carp in different treatments employed

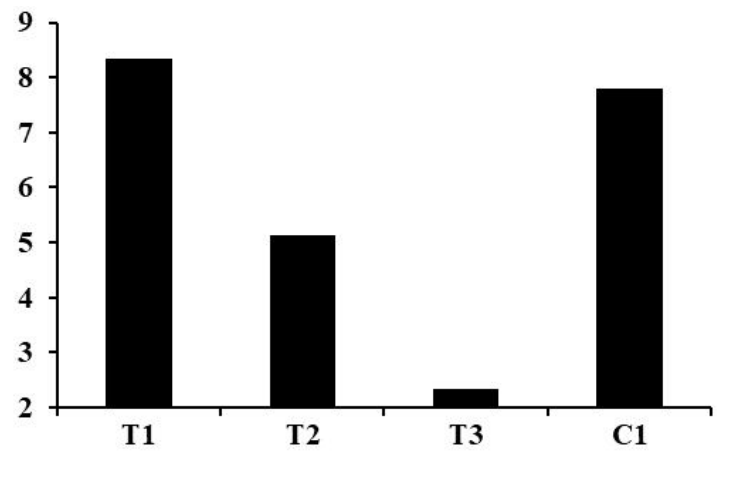

Fig. 4. Absolute growth of common carp in different treatments employed

the fact that FCE decreased polynomially $(\mathrm{y}=$ $2.288 \mathrm{x}^{2}-16.04 \mathrm{x}+70.81 ; \mathrm{R}^{2}=1$ ) with an identical reverse trend in FCR with identical fit ( $\mathrm{y}=$ $-0.057 \mathrm{X}^{2}+0.506 \mathrm{x}+1.30 ; \mathrm{R}^{2}=1$ ) (Fig. 9). So, it was clear that biofloc improved the performance of feed both in terms FCR and FCE.

The physicochemical conditions of the biofloc treatments remained congenial all throughout. Increase in the concentration of all the major nutrients like ortho-phosphate, ammonianitrogen and nitrate-nitrogen in the feed supplemented treatments was because of the uneaten feed and metabolic by-products as well. 


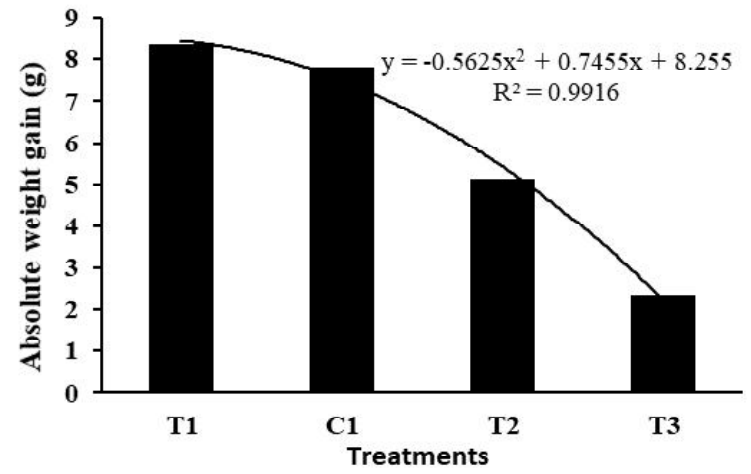

Fig. 5. Modular trend in absolute weight gain in different treatments employed

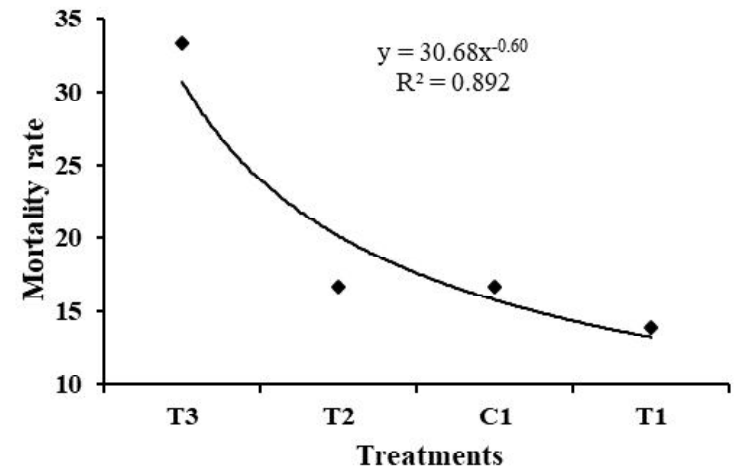

Fig. 7. Modular trend of mortality rate of fish in different treatments employed

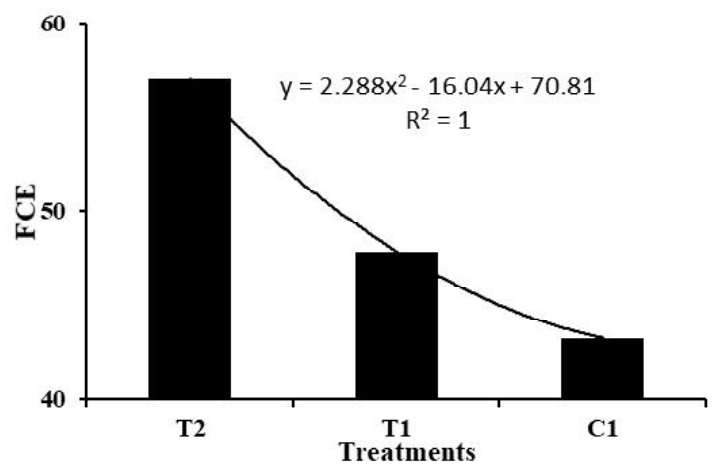

Fig. 9. Modular trend of FCE in different treatments employed

Moreover, the resultant increase in $\mathrm{N}$ and $\mathrm{P}$ was subsequently manifested in higher growth of fish in the biofloc treated systems as

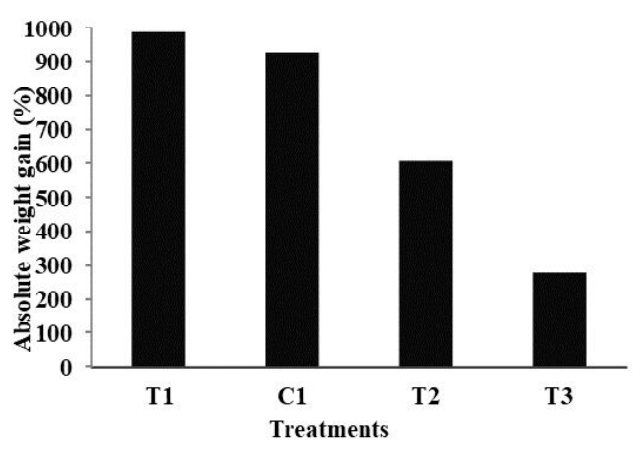

Fig. 6. Absolute weight gain (\%) of fish in different treatments employed

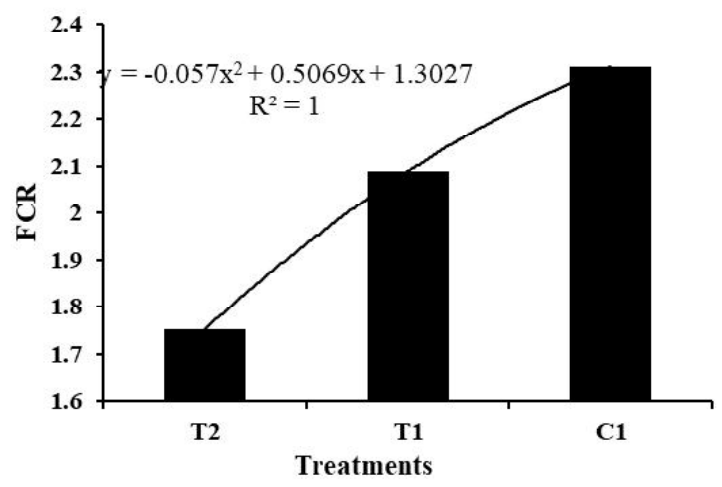

Fig. 8. Modular trend of FCR in different treatments employed

mobilization of nitrogen under suitable carbon reserve was effected in microbial protein synthesis as evidenced from the proximate composition of the floc. Again, higher presence of nutrients in the treatment with biofloc with fish $\left(\mathrm{T}_{3}\right)$ compared to its counterpart without fish $\left(\mathrm{C}_{2}\right)$ was because of the bioturbation effect of the test fish. Jana and Das (1992) and Jana et al. (2001) conclusively observed that benthivorous fish like Cyprinus carpio L. was effective in increasing the nutrient status of water through bioturbation of the sediment.

From the results of the present study it was 
indicated that in-situ biofloc production has the potential of reducing the cost towards feed and overall production. Moreover, the ecological health of the culture units with regards to physicochemical properties will also be improved with this technology.

\section{REFERENCES}

Albuquerque CS, Rabello CBV, Santos MJB, Lima MB, Silva EP et al., 2014. Chemical composition and metabolizable energy values of corn germ meal obtained by wet milling for layers. Revista Brasileira de Ciência Avícola, 16(1): 107-112

Anon, 1983. First 138 case studies of composite fish culture in India. Bulletin No-23, Central Inland Fisheries Research Institute, Barraackpur, West Bengal, pp153

APHA, 1995. Standard Methods for the Examination of Water and Waste Water. 16 ${ }^{\text {th }}$ edn., American Public Health Association, American Water Works Association and Water Pollution Control Federation, Washington, D. C., pp129

Avnimelech Y, 1999. Carbon/nitrogen ratio as a control element in aquaculture systems. Aquaculture, 176(3-4): 227-235

Avnimelech Y, 2007. Feeding with microbial flocs by tilapia in minimal discharge bioflocs technology ponds. Aquaculture, 264: 140-147

Avnimelech Y, 2012. Biofloc Technology - A Practical Guide Book, $2^{\text {nd }}$ edn., The World Aquaculture Society, Baton Rouge, Louisiana, EUA, pp272

Burford MA, Thompson PJ, McIntosh PR, Bauman RH and Pearson DC, 2004. The contribution of flocculated material to shrimp (Litopenaeus vannamei) nutrition in a high-intensity, zero exchange system. Aquaculture, 232: 525-537

\section{ACKNOWLEDGEMENT}

The first author acknowledges the Department of Aquaculture, Faculty of Fishery Sciences, West Bengal University of Animal and Fishery Sciences for providing the experimental farm and laboratory facilities.

Chu CP and Lee DJ, 2004. Multiscale structures of biological flocs. Chem Eng Sci, 59(8-9): 18751883

Connor WE, 2000. Importance of n-3 fatty acids in health and disease. The American J Clinical Nutri, 71(1): 171S-175S

Crab R, Defoirdt T, Bossier P and Verstraete W, 2012. Biofloc technology in aquaculture: Beneûcial effects and future challenges. Aquaculture, 356-357: 351-356

de Deckere E, Korver O, Verschuren PM and Katan MB, 1998. Health aspects of fish and n-3 polyunsaturated fatty acids from plant and marine origin. Eurepean J Clinic Nutri, 52: 749-753

De Silva SS and Anderson TA, 1995. Fish nutrition in aquaculture. Chapman and Hall, London, pp31

EPA, 2009. Drinking Water Standards and Health Advisories. Washington: USEPA Office of Drinking Water

FAO, 2010. The State of World Fisheries and Aquaculture. Food and Agriculture Organization of the United Nations, Rome

FAO, 2014. The State of World Fisheries and Aquaculture: Opportunities and Challenges. Food and Agricultural Organization of the United Nations, Rome

Goddard S, 1996. Feed Management in Intensive 
Aquaculture. Chapman and Hall Publishers, Fisheries and Marine Institute Memorial University Newfoundland, Canada

Hargreaves JA, 2006. Photosynthetic suspendedgrowth systems in aquaculture. Aquacult Eng, 34(3): 344-363

Hargreaves JA, 2013. Biofloc production systems for aquaculture. Southern Regional Aquaculture Center. SRAC Publication No. 4503, pp1-12

Horrocks LA and Yeo YK, 1999. Health benefits of docosahexaenoic acid (DHA). Pharmacol Res, 40(3): 211-225

Jackson ML, 1967. Soil Chemical Analysis. Prentice-Hall of India Pvt. Ltd., New Delhi, India, pp498

Jana BB and Das SK, 1992. Bioturbation induced changes of fertilizer value of phosphate rock in relation to alkaline phosphatase activity. Aquaculture, 103(3-4): 321-330

Jana BB, Chakraborty P, Biswas JK and Ganguly S, 2001. Biogeochemical cycling bacteria as indices of pond fertilization: importance of CNP ratios of input fertilizers. J Applied Microbiol, 90(5): 733-740

Kuhn DD, Boardman GD, Lawrence AL, Marsh L and Flick Jr. GJ, 2009. Microbial floc meal as a replacement ingredient for fish meal and soybean protein in shrimp feed. Aquaculture, 296(1-2): 51-57

MPEDA, 1992. Handbook on shrimp farming, India, pp74

Naylor RL, Goldburg RJ, Primavera JH, Kautsk N, Beveridge et al., 2000. Effect of aquaculture on world fish supplies. Nature, 405(6790): 1017-1024
Péron G, Mittaine JF and Le Gallic B, 2010. Where do fishmeal and fish oil products come from? An analysis of the conversion ratios in the global fishmeal industry. Marine Policy, 34(4): 815-820

Ruxton CHS, Calder PC, Reed SC and Simpson MJA, 2005. The impact of long-chain n-3 polyunsaturated fatty acids on human health. Nutr Res Rev, 18(1): 113-129

Santos MJB, Ludke MCMM, Ludke JV, Torres TR, Lopes LS et al., 2013. Chemical composition and metabolizable energy values of alternative ingredients for broilers. Ciência Animal Brasileira, 14(1): 32-40

Sugiyama S, Staples D and Funge-Smith S, 2004. Contribution of fisheries and aquaculture in the Asia Pacific. In: Status and potential of fisheries and aquaculture in Asia and the Pacific, RAP Publication, FAO Corporate Document Repository, FAO, Rome

Tacon AGJ, Cody JJ, Conquest LD, Divakaran S, Forster IP et al., 2002. Effect of culture system on the nutrition and growth performance of Pacific white shrimp Litopenaeus vannamei (Boone) fed different diets. Aquacult Nutr, 8(2): 121-137

Tidwell JH and Allan GL, 2001. Fish as food: aquaculture's contribution. EMBO Reports, 2(11): 958-963

Veerina SS, Nandeesha MC and Rao KG, 1993. Status and technology of Indian major carp farming in Andhra Pradesh, India. Asian Fisheries Society, Special Publication No.- 9, pp76

Walkley AJ and Black IA, 1934. Estimation of soil organic carbon by the chromic acid titration method. Soil Sci, 37, 29-38 